\title{
Identification of non-indigenous phytoplankton species dominated bloom off Goa using inverted microscopy and pigment (HPLC) analysis
}

\author{
P V Bhaskar ${ }^{1,3, *}$, Rajdeep Roy ${ }^{2}$, Mangesh Gauns ${ }^{2}$, D M Shenoy ${ }^{2}$, \\ $\mathrm{V}$ D RAO ${ }^{2}$ and $\mathrm{S}$ MOCHEMADKAR ${ }^{2}$ \\ ${ }^{1}$ CIMA, Faculty of Science 83 Technology, Campus de Gambelas, Universidad do Algarve, Faro, Portugal. \\ ${ }^{2}$ National Institute of Oceanography, Dona Paula, Goa 403 004, India. \\ ${ }^{3}$ Present address: National Centre for Antarctic and Ocean Research (NCAOR), Ministry of Earth Sciences, \\ Headland Sada, Vasco-da-Gama, Goa 403 804, India. \\ *Corresponding author.e-mail: pbhaskar23@gmail.com
}

An unusual phytoplankton bloom dominated by unidentified green coloured spherical algal cells $(\sim 5 \mu \mathrm{m}$ diameter) and dinoflagellates (Heterocapsa, Scripsiella and Gymnodinium) was encountered along the coast of Goa, India during 27 and 29 January, 2005. Pigment analysis was carried out using both fluorometric and HPLC methods. Seawater samples collected from various depths within the intense bloom area showed high concentrations of Chl $a$ (up to $106 \mathrm{mg} \mathrm{m}^{-3}$ ) associated with low bacterial production ( 0.31 to $0.52 \mathrm{mg} \mathrm{C} \mathrm{m}{ }^{-3} \mathrm{~h}^{-1}$ ) and mesozooplankton biomass $\left(0.03 \mathrm{ml} \mathrm{m}^{-3}\right)$. Pigment analyses of the seawater samples were done using HPLC detected marker pigments corresponding to prasinophytes, dinoflagellates and diatoms. Chlorophyll $b(36-56 \%)$ followed by peridinin (15-30\%), prasinoxanthin (11-17\%) and fucoxanthin (7-15\%) were the major diagnostic pigments while pigments of cryptophytes and cyanobacteria including alloxanthin and zeaxanthin formed $<10 \%$. Although microscopic analysis indicated a decline in the bloom, pheaophytin concentrations in the water column measured by both techniques were very low, presumably due to fast recycling and/or settling rate. The unique composition of the bloom and its probable causes are discussed in this paper.

\section{Introduction}

Coastal and near-shore waters are more productive regions in the marine environment nourished by nutrients derived by regeneration, upwelling and land run-off. Phytoplankton blooms in these waters follow a seasonal pattern that shapes the coastal marine ecosystem. Environmental forcing, nutrient availability, predator communities and land-driven inputs are the major factors that control coastal and near-shore phytoplankton community and blooms. Several anthro- pogenic factors in these environments can result in alteration of coastal water quality (eutrophication), introduction of non-native species (ballast action), alteration of predator community (over-fishing), etc. As a result, non-periodic and exceptional blooms of both noxious and/or toxic phytoplankton species lasting for few weeks to months are frequently reported, influencing the seasonal patterns of dominant phytoplankton community structure, thereby affecting coastal and estuarine biogeochemical processes (Cloern 1996).

Keywords. Dinoflagellates; prasinoxanthin; HPLC; pigment composition; phytoplankton bloom. 
The primary production and phytoplankton community in the waters along the coast of India are largely influenced by monsoonal forcings, resulting in changes in the coastal currents, surface temperatures, nutrient availability, etc. For example, Banse et al (1996) hypothesized increased nutrient supply as principal factor controlling primary production in the western coastal waters of India. Along with nutrient injection in the coastal waters, seasonal changes in the surface coastal current directions (Shetye et al 1994) coupled with changes in salinity and temperature regulate the phytoplankton diversity along west coast of India (Qasim 1977). Phytoplankton diversity, blooms and their life stages have been exhaustively studied in these waters following the classical microscopy methods (Subrahmanyan 1958; Dehadrai and Bhargava 1972; Devassy et al 1978; Sawant and Madhupratap 1996), remote sensing (Desa et al 2005; Gomes et al 2008), molecular techniques (Godhe et al 2001) and of late using pigment identification by HPLC technique (Roy et al 2006; Parab et al 2006; Roy 2010). All these studies show that diatoms are the pre-dominant forms of phytoplankton followed by seasonal blooms of dinoflagellates and Trichodesmium.

In the recent past, 'unusual blooms' of phytoplankton species unrelated to the seasonally recurring communities have been reported. Some of these blooms have been either toxic (Sahayak et al 2005), caused nuisance to coastal population (Ramaiah et al 2005) or led to discolouration of coastal waters (Nayar et al 2001). Moreover, the frequency of these blooms in the near-shore waters of the west coast of India has increased which reportedly coincide with increased commercial shipping in these waters (Anil et al 2002). One common trait in all these blooms - harmful or otherwise was their sporadic nature; most of them were never encountered earlier and their occurrences in these waters were largely uncommon. Here we report one such occurrence of phytoplankton bloom in the near-shore waters of Goa, west coast of India dominated by cells hitherto not observed in these waters. Moreover, an attempt is made to explain possible cause of this bloom in these waters.

\section{Material and methods}

\subsection{Study site and sampling}

The mixed phytoplankton bloom was observed during one of the monthly sampling at the Candolim time series (CaTS) transect (figure 1) in the near-shore waters off Goa, west coast of India. Seawater was sampled on two days (27 and 29 January,

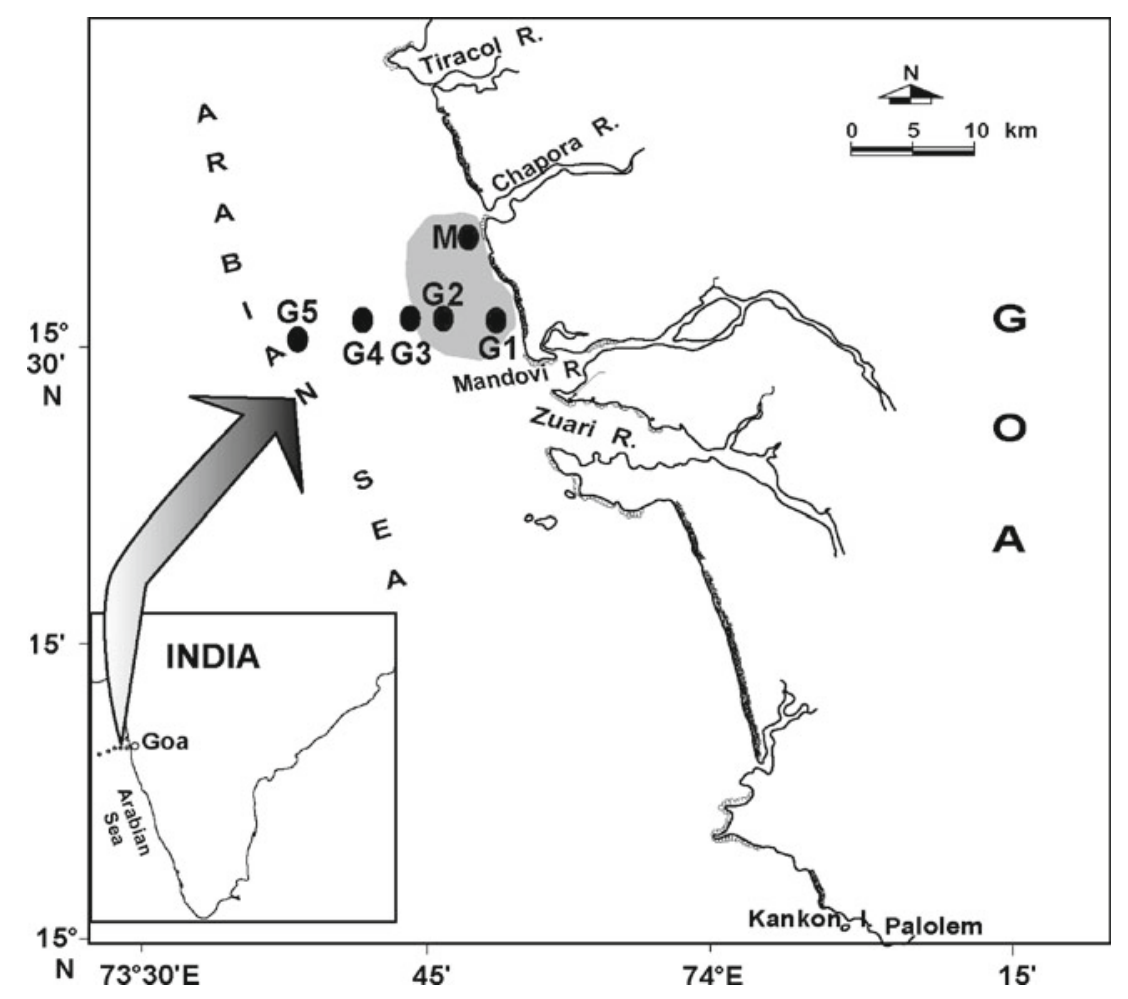

Figure 1. Map showing the CaTS (Candolim time-series) stations G1 to G5 and one station off Morjim north of CaTS. The approximate spread of the bloom is indicated by the shaded portion. 
2005). On the first day of sampling, seawater from three stations (G1, G2, G3) along the CaTS transect (table 1) were sampled. On the subsequent day, sampling was restricted to G1, G2 and station off Morjim (M) (figure 1).

Seawater was collected using a 5 litre Niskin sampler and sub-samples were collected for phytoplankton enumeration and its generic composition, chlorophyll $a(\mathrm{Chl} a)$, pigment composition and bacterial production.

\subsubsection{Chl $a$ and other pigments}

Aliquots of seawater were filtered on $\mathrm{GF} / \mathrm{F}$ $(0.7 \mu \mathrm{m})$ filters for chlorophyll $a$ and pigment composition. The Chl $a$ filters were extracted immediately after filtration whereas pigment samples were stored in liquid nitrogen prior to analyses. Both Chl $a$ and pigment samples were extracted in $90 \%$ acetone under refrigeration.

\subsubsection{Phytoplankton abundance}

Samples for phytoplankton abundance and composition were fixed with Lugol's iodine and stored in dark prior to microscopic examination.

\subsubsection{Bacterial production}

Ten millilitre of unfiltered samples were spiked with $20 \mu \mathrm{l}$ of ${ }^{3} \mathrm{H}_{1}$-thymidine $(1 \mathrm{mCi}$; specific acitivity: $12,000 \mathrm{mCi} \mathrm{mmol}^{-1}$ ) in triplicates and incubated for 60 minutes in the dark in ambient conditions. The uptake was stopped by adding $0.2 \mu \mathrm{m}$ filtered formalin ( $4 \%$ final concentration). Formalin prefixed samples were used as controls and were incubated similarly.

Additional sample for mesozooplankton biomass was collected using towing method (HT net, $200 \mu \mathrm{m}$ mesh) and the samples were preserved in $4 \%$ formalin. All the samples were brought back to the laboratory within 3 hours of sampling for further processing and were stored in ice during transport.

\subsection{Analyses}

Chlorophyll $a(\mathrm{Chl} a)$ and phaeophytin concentrations were measured fluorometrically on a Turner fluorometer (UNESCO 1994). For estimation of Chl $a$, the filter paper containing the sample was crushed and the pigments were extracted in $10 \mathrm{ml}$ of $90 \%$ acetone in dark for $24 \mathrm{~h}$ in the refrigerator. After extraction, the fluorescence was measured before $\left(F_{o}\right)$ and after acidification $\left(F_{a}\right)$ with two drops of $1.2 \mathrm{~N} \mathrm{HCl}$. The actual concentrations of Chl $a$ and phaeophytin pigments were then calculated following JGOFS protocol (UNESCO 1994).

The total pigment samples were analyzed following a slightly modified method described by van Heukelem (2002) as described by Roy et al (2006). The HPLC system was equipped with an Eclipse XDB C-8 reverse phase column $(4.6 \times 150 \mathrm{~mm})$ attached to a guard column, an Agilent 1100 pump, online degasser and diode array detector (Agilent Technologies Model 1100). The column was maintained at $60^{\circ} \mathrm{C}$ and the elution was carried out using a linear gradient program over $36 \mathrm{~min}$ at the rate of $1.1 \mathrm{ml} \mathrm{min}{ }^{-1}$. The eluant was a mixture of solvent A (methanol (70:30) + 1 M ammonium acetate ( $\mathrm{pH} \mathrm{7.2))}$ and solvent $\mathrm{B}$ (methanol). The solvents A and B were mixed from $95 / 5 \%$ to $5 / 95 \%$ for the first $22 \mathrm{~min}$ followed by an isocratic separation with $95 \%$ solvent B up to $30 \mathrm{~min}$ to elute $\alpha$ - and $\beta$-carotenes. The column was equilibrated for $6 \mathrm{~min}$ between two successive analyses. The pigments were detected using a UV-diodearray detector. Pigment standards (DHI Waters, Denmark and Sigma-Aldrich, USA) for Chl $a$ and 15 different marker pigments were used to identify and quantify various phytoplankton groups. The marker pigments were chlorophyll $\mathrm{c}_{2}\left(\mathrm{Chl} \mathrm{c}_{2}\right)$,

Table 1. Distribution of chlorophyll a, phaeophytins and total bacterial production (BP) during the bloom period in the near shore waters off Goa.

\begin{tabular}{|c|c|c|c|c|c|c|c|c|c|c|c|c|}
\hline \multirow{4}{*}{$\begin{array}{l}\text { Location } \\
\text { Parameters }\end{array}$} & \multicolumn{7}{|c|}{$27 / 01 / 2005$} & \multicolumn{5}{|c|}{$29 / 01 / 2005$} \\
\hline & \multicolumn{2}{|c|}{ G1 } & \multicolumn{2}{|c|}{ G2 } & \multicolumn{3}{|c|}{ G3 } & \multicolumn{2}{|c|}{ G1 } & G2 & \multicolumn{2}{|c|}{ Off Morjim } \\
\hline & \multicolumn{2}{|c|}{$\begin{array}{l}73.45 .6^{\circ} \mathrm{E} \\
15.31 .2^{\circ} \mathrm{N}\end{array}$} & \multicolumn{2}{|c|}{$\begin{array}{l}73.44 .4^{\circ} \mathrm{E} \\
15.31 .2^{\circ} \mathrm{N}\end{array}$} & \multicolumn{3}{|c|}{$\begin{array}{l}73.43 .8^{\circ} \mathrm{E} \\
15.31 .2^{\circ} \mathrm{N}\end{array}$} & \multicolumn{2}{|c|}{$\begin{array}{l}73.45 .6^{\circ} \mathrm{E} \\
15.31 .2^{\circ} \mathrm{N}\end{array}$} & $\begin{array}{l}73.44 .4^{\circ} \mathrm{E} \\
15.31 .2^{\circ} \mathrm{N}\end{array}$ & \multicolumn{2}{|c|}{$\begin{array}{l}73.43 .4^{\circ} \mathrm{E} \\
15.37 .4^{\circ} \mathrm{N}\end{array}$} \\
\hline & $1 \mathrm{~m}$ & $4 \mathrm{~m}$ & $1 \mathrm{~m}$ & $9 \mathrm{~m}$ & $1 \mathrm{~m}$ & $7 \mathrm{~m}$ & $14 \mathrm{~m}$ & $1 \mathrm{~m}$ & $4 \mathrm{~m}$ & $1 \mathrm{~m}$ & $1 \mathrm{~m}$ & $6 \mathrm{~m}$ \\
\hline Chlorophyll $a$ & 106.8 & 3.2 & 17.6 & 1.4 & 6.5 & 3.4 & 0.7 & 22.9 & 11.7 & 19.8 & 18.7 & 3.8 \\
\hline Phaeophytins & 0.84 & 0.37 & 0 & 0.73 & 0 & 0.1 & 0.73 & 0 & 0 & 0.4 & 0.3 & 1.1 \\
\hline $\mathrm{BP}$ & nd & nd & nd & nd & nd & nd & nd & 0.52 & 0.33 & nd & 0.31 & 0.34 \\
\hline
\end{tabular}

Chlorophyll $a$ and phaeophytins concentrations are in $\mathrm{mg} \mathrm{m}^{-3}$; bacterial production (BP) is in $\mathrm{mg}_{-} \mathrm{C} \mathrm{m}^{-3} \mathrm{~h}^{-1}$. nd: not done. 
chlorophyll $\mathrm{c}_{3}\left(\mathrm{Chl} \mathrm{c}_{3}\right)$, peridinin (Per), fucoxanthin (Fuc), 19' butanoyloxyfucoxanthin (19' BF), neoxanthin (Neo), violaxanthin (Viola), prasinoxanthin (Pra), alloxanthin (Allo), 19' hexanoyloxyfucoxanthin (19' HF), diadinoxanthin (Diad), zeaxanthin (Zea), lutein (Lut), chlorophyll $b$ (Chl $b)$, total carotene $(\alpha+\beta$, Tcar), chlorophyll a (Chl a) and phaeophytin (Phaeo $a$ ). Diagnostic pigment (DP) concentrations were calculated as described by Roy et al (2006) after including Pra as prasinoxanthin also contributed significantly to the pigment concentration. The standards for carotenes ( $\alpha$ - and $\beta$-types) were purchased individually from DHI Waters and calibrated as a mixture. Both forms of carotenes had similar elution time and could not be resolved properly. Therefore, the two carotenes were grouped together and expressed as Tcar. All the other chemicals used were procured from Merck (Germany).

The samples collected for phytoplankton composition and enumeration were examined following sedimentation technique using Utermohl's inverted microscope (Hasle 1978).

The samples for bacterial production was filtered onto $0.2 \mu \mathrm{m}$ cellulose nitrate filters, extracted in cold trichloroacetate (TCA), the paper dissolved in scintillation cocktail (UNESCO 1994) and activity measured using a scintillation counter (Wallac model 2000). Zooplankton biomass was estimated by volume displacement method (Madhupratap and Haridas 1990).

\section{Results}

On day 1 of sampling, the sampled waters at G1 and G2 were dirty brown in colour compared to surface waters outside the patch (figure 2). The patch was tracked up to Morjim and appeared to be concentrated in near shore waters. A similar distinct horizontal and vertical spatial variation was also observed in all the major parameters (table 1). The surface Chl $a$ concentration decreased from $106.8 \mathrm{mg} \mathrm{m}^{-3}$ at G1 to $6.5 \mathrm{mg} \mathrm{m}^{-3}$ at G3. A similar decrease with depth was also observed at all stations (table 1). The depth and spatial profile of Chl $a$ indicated that the bloom cells were concentrated close to the shores. During the subsequent sampling, the surface Chl $a$ value at G1 dropped to $22.9 \mathrm{mg} \mathrm{m}^{-3}$ with a substantial increase in near bottom chlorophyll concentrations to $11.7 \mathrm{mg} \mathrm{m}^{-3}$. The spatial spread of the bloom up to Morjim was evident as the surface $\mathrm{Chl} a$ concentrations remained nearly same. The phaeophytin concentration after acidification of Chl $a$ samples was always less than $1 \mathrm{mg} \mathrm{m}^{-3}$ during the sampling.

HPLC analysis of the pigment samples detected a range of diagnostic pigments (DP) specific for dinoflagellates, prasinophytes, diatoms, cyanobacteria and cryptophytes (figure 3 ). Unlike the fluorometric method, the HPLC method measured low Chl $a$ concentrations $\left(4.1-6.5 \mathrm{mg} \mathrm{m}^{-3}\right)$ in the surface waters at G1 and Morjim. Based on the DP calculation, the bloom was dominated by $\mathrm{Chl} b$ (36-56\%), peridinin (15-30\%), prasinoxanthin $(11-17 \%)$ and fucoxanthin $(7-15 \%)$ (figure 3$)$. The concentration of the prasinoxanthin was higher in surface waters compared to other pigments. Other DP including diadinoxanthin, zeaxanthin, alloxanthin, etc., contributed $<5 \%$, respectively.

Microscopic observations showed that the bloom was dominated by unidentified unicellular green coloured algal cells during both days of sampling (figure 4). On the first day of sampling, the bloom cells completely covered the field area and formed aggregates. The cells were covered with mucus

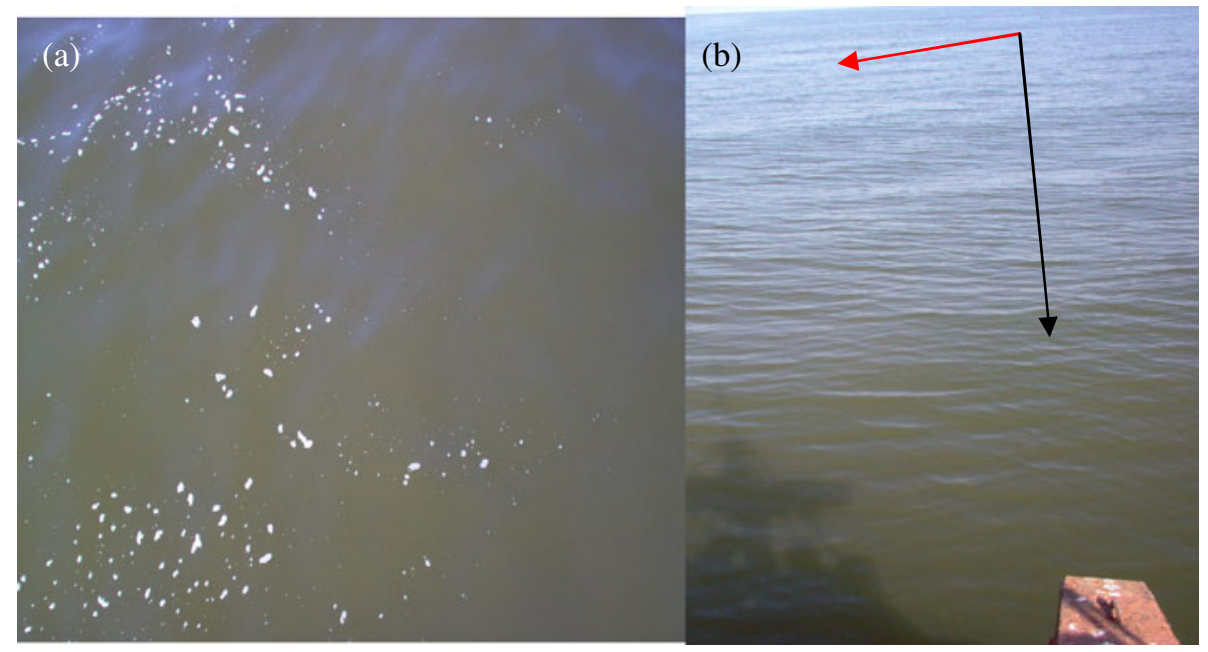

Figure 2. Photographs of (a) surface waters from within the bloom patch showing distinct muddy colour and (b) edge of the bloom patch showing different colours outside (red arrow) and inside (black arrow) the bloom patch. 
(a)

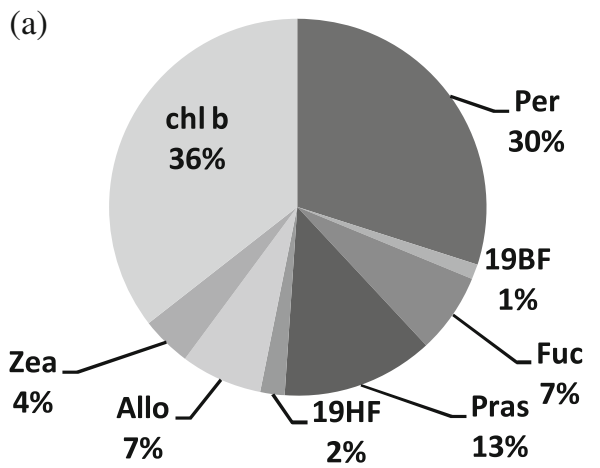

(c)

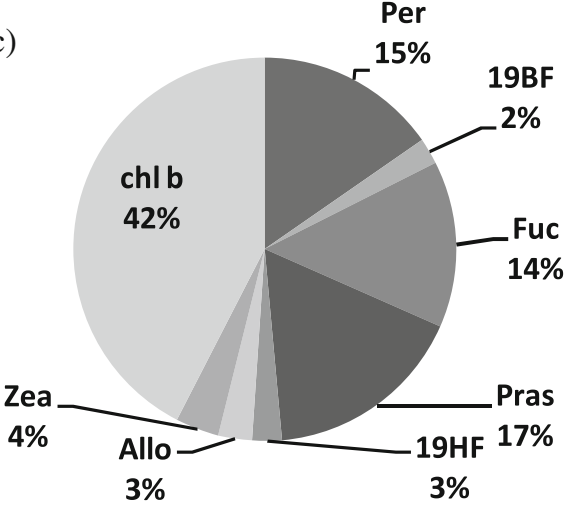

(b)

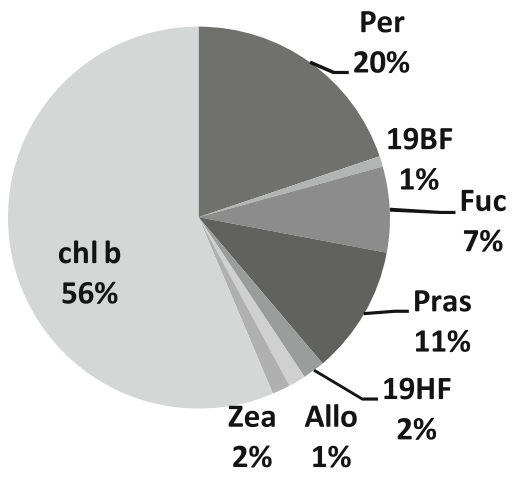

(d)

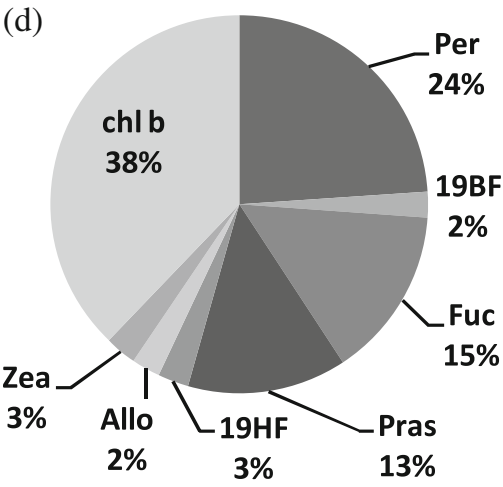

Figure 3. Percent distribution of major diagnostic pigments identified using HPLC method in samples collected from (a) G1 surface, (b) G1 4 m, (c) Morjim surface, and (d) Morjim $6 \mathrm{~m}$.

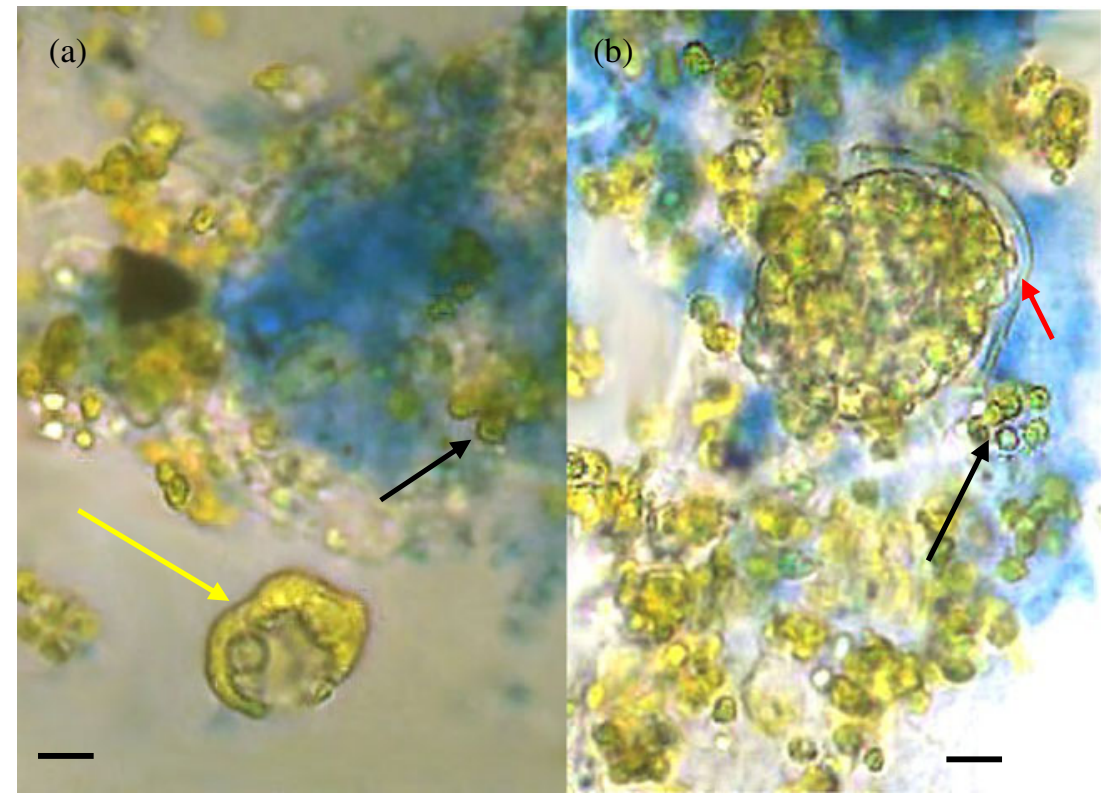

Figure 4. Microphotographs of the bloom sample showing (a) broken dinoflagellates cell (yellow arrow) and (b) an intact dinoflagellate containing green unidentified cells (red arrow). Also note the unidentified green cells and the mucus stained with alcian blue in the background (black arrows). Scale in each photograph equals $10 \mu \mathrm{m}$.

which could be stained with Alcian blue. The cells could not be disaggregated without causing cell breakage and hence were difficult to count. The samples contained broken as well as intact green coloured unidentified algal cells as well as dinoflagellates (figure 4a and b). The ruptured cell-walls of algae as observed microscopically suggested that many of these cells were in a state of decay and 
Table 2. The composition of the major phytoplankton genera identified in the surface waters at G1 station.

\begin{tabular}{|c|c|c|}
\hline $\begin{array}{l}\text { Phytoplankton } \\
\text { composition }\end{array}$ & $27 / 01 / 2005$ & $29 / 01 / 2005$ \\
\hline \multicolumn{3}{|l|}{ Diatoms } \\
\hline Amphora sp. & - & 300 \\
\hline Navicula sp. & 8000 & 200 \\
\hline Nitzschia sp. & 1333 & 200 \\
\hline Coconeis sp. & 2000 & \\
\hline Coscinodiscus sp. & - & 800 \\
\hline Pleurosigma sp. & 800 & 100 \\
\hline \multicolumn{3}{|l|}{ Dinoflagellates } \\
\hline Amphidinium sp. & 4000 & - \\
\hline Ceratium sp. & - & 600 \\
\hline Dinophysis sp. & - & 100 \\
\hline Gymnodinium sp. & 8000 & 200 \\
\hline Gyrodinium sp. & 12000 & 200 \\
\hline Heterocapsa sp. & 34667 & - \\
\hline Prorocentrum sp. & 38666 & 400 \\
\hline Protoperidinium sp. & 4000 & 500 \\
\hline Scrippsiella sp. & 145333 & - \\
\hline \multicolumn{3}{|l|}{ Silicoflagellates } \\
\hline Dictyocha sp. & 1333 & - \\
\hline Distephanus sp. & - & 200 \\
\hline Unidentified algal cells & $\mathrm{NC}$ & 1150000 \\
\hline Total cells $\mathrm{L}^{-1}$ & 263866 & 1153800 \\
\hline
\end{tabular}

NC: Not counted.

the bloom was in the declining phase. The surface samples collected subsequently showed that the unidentifiable cells amounted to $\sim 99 \%$ of total

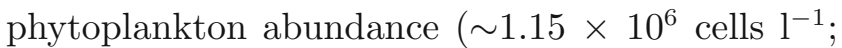
table 2). Phytoplankton cells other than the bloom cells decreased from $2.6 \times 10^{5}$ cells $1^{-1}$ on the

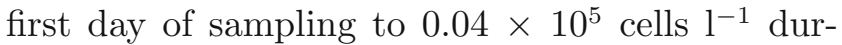
ing the subsequent sampling. Among these phytoplankton cells, dinoflagellates constituted $\sim 93.5 \%$ $\left(2.4 \times 10^{5}\right.$ cells $\left.^{-1}\right)$ on the first day of sampling. During the second day of sampling, the contribution of dinoflagellate decreased to $\sim 56 \%$. Heterocapsa sp., Scripsiella sp. and Gymnodinium sp. dominated the dinoflagellates community (table 2). Diatoms formed $<4 \%$ of the total phytoplankton population.

Bacterial production rates were low and ranged from 0.31 to $0.52 \mathrm{mg} \mathrm{C} \mathrm{m}^{-3} \mathrm{~h}^{-1}$ (table 1 ). Copepods formed the bulk of the mesozooplankton population $(>200 \mu \mathrm{m})$ and the total mesozooplankton biomass was $0.03 \mathrm{ml} \mathrm{m}^{-3}$.

\section{Discussion}

A mixed phytoplankton bloom at the CaTS stations was a chance observation and unique for these waters. The bloom was largely composed of green coloured spherical cells which were 4$5 \mu \mathrm{m}$ in diameter and covered in mucus exudates (figure $4 \mathrm{a}$ and $\mathrm{b}$ ). Moreover, the bloom was mainly confined to the shallow waters (depth $12 \mathrm{~m}$ ), forming clumps of cells. The west coast of India largely experiences weak sea-breeze (1.5 to $5 \mathrm{~m} \mathrm{~s}^{-1}$ ) between November and April and wind direction is almost along the coastline at the CaTS. The cross shore component of the winds changes from land-sea in the mornings to sea-land in the afternoons (Neetu et al 2006). The sampling stations experience the West India Coastal Currents (WICC) that brings in low saline, warm and nutrient depleted waters from the south (Shetye 1999; Naqvi et al 2003). Such hydrographic conditions support diatoms and dinoflagellates (Devassy and Goes 1989) which were also observed in this mixed phytoplankton bloom. Moreover, earlier reports suggest that diatoms (55\%) and dinoflagellates $(36 \%)$ constitute the phytoplankton population in the waters around CaTS (Parab et al 2006). The existing meteorological and hydrodynamic conditions suggest that the bloom might have developed off-shore and migrated to the coast over time, resulting in extremely high concentrations of Chl $a$ in the surface waters.

This is the first report of a bloom in these waters wherein prasinoxanthin contribution was up to $17 \%$ of the diagnostic pigments. The waters in and around CaTS area is predominantly diatom based ecosystem with seasonal blooms of other phytoplankton species like Trichodesmium and a few dinoflagellates (Devassy and Goes 1988; Desa et al 2005) and prasinoxanthin pigment generally constitutes $<5 \%$ of the pigment suite analyzed in these waters (Parab et al 2006). Our assessment of the mixed bloom is based on the combination of microscopic observations (table 2; figure 4) and measurements of marker pigments using HPLC (figure 3). Prasinoxanthin is a biomarker pigment for cells of class Prasinophyceae whereas Chl $b$ appears in a range of phytoplankton groups including prasinophytes, euglenophytes and chlorophytes (Gibb et al 2001). All the microscopically identified phytoplankton species in this bloom do not contain prasinoxanthin and also do not contain endosymbionts that may have the marker pigment. Since the unidentified cells were the most abundant cells and the dinoflagellates identified in this bloom were not the source of prasinoxanthin, we believe that the presence of prasinoxanthin in the samples could be attributed to these cells. In the absence of clear taxonomic information using microscopy, we can only speculate that the unidentified algal cell may belong to class Prasinophyceae. 
Table 3. Blooms of non-indigenous species reported from west coast of India.

\begin{tabular}{|c|c|c|c|c|}
\hline No. & Bloom events & Dominant sp. & Bloom effect & Reference \\
\hline 1 & Trichodesmium bloom & Trichodesmium sp. & Dark brown discolouration & Devassy et al (1978) \\
\hline 2 & Dinoflagellate bloom & Gymnodinium nagasakiense & Red discolouration & $\begin{array}{l}\text { Karunasagar and } \\
\text { Karunasagar (1992) }\end{array}$ \\
\hline 3 & Dinoflagellate bloom & Noctiluca sp. & Red discolouration \& fish kill & Naqvi et al (1998) \\
\hline 4 & Dinoflagellate bloom & Noctiluca milaris & Red discolouration & Nayak et al (2000) \\
\hline 5 & Dinoflagellate bloom & Noctiluca scintillans & Red discolouration & Nayar et al (2001) \\
\hline 6 & Trichodesmium bloom & Trichodesmium sp. & Dark brown discolouration & Sarangi et al (2004) \\
\hline 7 & Dinoflagellate bloom & Noctiluca milaris & Red discolouration & Sahayak et al (2005) \\
\hline 8 & Holoccolithophorid bloom & $\begin{array}{l}\text { Unidentified holococco- } \\
\text { lithophore }\end{array}$ & Obnoxious stench & Ramaiah et al (2005) \\
\hline 9 & Mixed phytoplankton bloom & $\begin{array}{l}\text { Unidentified prasinoxanthin } \\
\text { containing algal cells }\end{array}$ & Dirty brown discolouration & Present study \\
\hline
\end{tabular}

Pigment to Chl a ratios are widely used to estimate the relative contribution of different phytoplankton groups (Mackey et al 1996) and is a function of the physiological state of the cells, ambient nutrient levels and photoadaptive stress (Falkowski and LaRoche 1991). The Pras: Chl a (0.01-0.03) and Chl $b$ : Chl $a$ ratios (0.034-0.132) in the bloom samples were much lower than those reported in culture studies of prasinophytes (Pras: Chl $a-0.097$ to 0.305 ; Chl $b$ : Chl $a-0.618$ to 1.313 ) (Latasa et al 2004). The lower pigment ratios in this study could be attributed to the age of the bloom, growth conditions and physiological stress. Another factor that may have skewed the pigment ratios in the present study was the contribution of Chl $a$ from diverse phytoplankton population. A direct comparison of pigment ratios of a mixed population to monoculture-based studies is therefore highly subjective.

The age of the bloom could not be ascertained and contrary to the low pheaophytin $a$ concentrations, the bloom had already entered the decline phase as evident from the decrease in Chl $a$ concentrations over the sampling days (table 1) and microscopy (figure 4). The dominance of dinoflagellates and copepods in the bloom samples may have resulted in the low phaeophytin $a$ concentrations. Accumulation of phaeophytin $a$ differs with different grazers and need not always increase during the decline of a bloom. Engelkes (1985) found that copepod grazing did not form phaeophytin $a$ from Chl $a$ whereas protozoans could digest chlorophylls to colourless residues (Burkill et al 1987). Moreover, microzooplankton reingest fecal pellets resulting in extensive degradation of pigments and fast recycling of pigments within water column (Strom 1993).

The bloom was unusual for various reasons including exceptionally high concentration of $\mathrm{Chl} a$ by fluorometry, unique composition, presence of prasinoxanthin pigments and low biological activity. High Chl $a$ concentrations by fluorometry was not reflected in HPLC method which may be due to combination of factors. Fluorometric analyses do not differentiate $\mathrm{Chl} a$ and $\mathrm{Chl} b$ and presence of phytoplankton groups with high amounts of Chl $b$ can produce a significant fluorescence anomaly due to changes in the accessory pigment composition (Lorenzen and Jeffrey 1980; Trees et al 1985, 2000). Variations in extraction procedures can result in discrepancy of up to $87 \%$ between the two analytical techniques (van Heukelem 2002). Other sources of discrepancies include differences in sample collection, sample storage, nature of standards used for sample analysis, etc. Despite these discrepancies, HPLC pigment measurement is considered to be more reliable as it separate and quantifies various pigments and their derivatives (Jeffrey et al 1999).

This bloom was one-time event in these waters and has never been encountered previously (table 3). Subsequent sampling during the same month in following years did not show any exceptional Chl $a$ values or phytoplankton composition. The stations along CaTS have been monitored continuously since mid 1990s and have been reported for its biogeochemistry (Naqvi et al 2003). Moreover, primary production and phytoplankton 
communities in these waters have been monitored regularly since 1970s (Dehadrai and Bhargava 1972; Qasim 1977; Devassy and Goes 1989; Parab et al 2006). The occurrences of 'unusual' bloom events have been reported globally with increasing frequency. One of the common features of all the 'unusual' blooms in coastal waters is the dominance of non-indigenous species (NIS) that may reoccur sporadically with or without adverse effect (Cloern 1996). For example, nuisance brown tides in the northeast coast of United States have been attributed to sporadic bloom of Aureococcus anophagefferens (Bricelj and Lonsdale 1997). Similarly, intense blooms of toxic dinoflagellate and holococcolithophorids causing large scale fish kill and foul smell production in the southwest coast of India have been recorded periodically (Karunasagar and Karunasagar 1992; Karunasagar et al 1989, 1990; Ramaiah et al 2005). Unlike toxic blooms, non-toxic bloom of a prymnesiophyte Phaeocystis globosa was first reported in the Arabian Sea by Madhupratap et al (2000). Nevertheless, non-toxic blooms of NIS generally go unreported due to lack of adequate attention and continuous monitoring of the coastal waters.

The presence of prasinoxanthin in the bloom samples raises questions about its origin. Prasinoxanthin pigments in bloom samples are generally limited to higher latitudes (Reigman and Kraay 2001; Schluter and Møhlenberg 2003; Ansotegui et al 2003; Yu et al 2007). Nevertheless, cells having prasinoxanthin have been reported from Gulf of Mexico (Guillard et al 1991), tropical waters (Hallaegraeff and Jeffrey 1984; McManus and Dawson 1994) and equatorial waters (Mackey et al 1998; Gin et al 2003). Based on the archival data (table 3) and the nature of the bloom, we believe that the dominant phytoplankton cells were alien to these waters and were accidentally introduced. The sampling area is close to Mormugao Port, which is one of the major shipping ports along the west coast of India (figure 1), and experiences intense shipping activity largely with China, Korea and southeast Asian countries. The introduction of alien microalgal species in Indian waters is well established (Subba Rao 2005); nine dinoflagellate species and one diatom species belonging to the coastal waters of China, Japan, Mediterranean, western Atlantic and Australia have been reportedly introduced in and around Indian waters in the last 50 years. With increased maritime activity in and around the sampling waters, it is likely that this non-native phytoplankton could have been transported via ballast waters of the ships and released into the sampling station.

Blooms of non-indigenous species are sporadic and depend upon the adaptability of these forms to new environment and avoid potential predators/ consumers. Apart from possible toxic/harmful effects, there is little information on the impacts of such blooms on the organic carbon composition and the stress on existing microbial foodweb and associated biological communities. During the unusual bloom at CaTS, phytoplankton carbon (Chl $a$-C) estimated using OC:Chl $a$ of 80 (Banse 1977) ranged from $8.5 \mathrm{~g} \mathrm{C} \mathrm{m}^{-3}$ at G1 (surface) to $56 \mathrm{mg} \mathrm{C} \mathrm{m}^{-3}$ at G3 (14 m) on the first day sampling. Some of our values were much higher than those reported which could be attributed to the Chl $a$ based carbon calculation adopted and under estimation of total organic carbon produced since dinoflagellates produce significant fraction of organic carbon as mucus exudates (figure 4b). The low microbial activity might be a reflection of the nature of organic matter produced during the bloom. Similar microbial response to organic carbon has been reported for a Phaeocystis bloom (Janse et al 2001). The low microbial activity and zooplankton biomass suggested that significant fraction of carbon fixed during the bloom escaped the food-web. The eventual sedimentation of such blooms and the shallow depth of the sampling stations would have increased organic carbon supply to the benthic communities that may influence their biomass and fecundity.

The ever increasing maritime activities around Indian waters raises concern about the vulnerability of the region to NIS through ballast water. It is very likely that similar blooms might be occurring along the Indian coastline but go largely unnoticed for want of continuous monitoring, awareness and effective mitigation measures both at policy formulation and implementation levels. Under Global Ballast Water Management Program of International Maritime Organization (IMO), extensive research on various aspects including baseline biota data, risk scenario development and analysis, GIS based database, development of demonstrable technologies for collection, supply and treatment of ballast water, etc. has been initiated at selected ports around the Indian coastline from 2001 (http://www.bwmindia.com/). These initiatives need to be further strengthened by proper documentation of such events and identification of NIS and related harmful events combined with effective coastal management tools is the need of the hour.

\section{Conclusions}

An unusual phytoplankton bloom dominated by unidentified cells and prasinoxanthin as one of the dominant pigments was encountered in a diatomdominated marine environment in the near-shore waters off Goa. Based on the timing of the bloom, 
morphology and pigment composition, we believe that this bloom was caused by a non-indigenous species which might have been introduced via ballast water discharge. The accumulation of bloom cells and dinoflagellates in a small patch in shallow waters combined with low bacterial production and zooplankton biomass resulted in unusually high concentrations of organic carbon. Although no immediate harmful impact of the bloom was evident, further studies are required to ascertain the impact of similar blooms on the microbial population, microbial loop and benthic fauna.

\section{Acknowledgements}

The authors wish to thank the Director, NIO for the infrastructural facilities and support. The authors would like to acknowledge Dr S W A Naqvi and Dr M Dileep Kumar for their valuable suggestions to improve the manuscript. They also like to thank the unknown reviewers for the valuable suggestions and positive criticism which helped in improving the quality of this paper. RR acknowledges NIO for his fellowship. This work is funded by CSIR under the CSIR-Network project CMM-0009. This is NIO's contribution number 5017.

\section{References}

Anil A C, Venkat K, Sawant S S, Dileep Kumar M, Dhargalkar V K, Ramaiah N, Harkantra S N and Ansari Z S 2002 Marine bioinvasion: Concern for ecology and shipping; Curr. Sci. 83(3) 214-218.

Ansotegui A, Sarobe A, Trigueros J M, Urrutxurrtu I and Orrive E 2003 Size distribution of algal pigments and phytoplankton assemblages in a coastal-estuarine environment: Contribution of small eukaryotic algae; J. Plank. Res. 25 341-355.

Banse K 1977 Determining carbon to chlorophyll ratio of natural phytoplankton; Mar. Biol. 41 199-212.

Banse K, VijayRaghavan S and Madhupratap M 1996 On the possible causes of seasonal phytoplankton blooms along the southwest coast of India; Indian J. Mar. Sci. 25 283-289.

Bricelj V M and Lonsdale D J 1997 Aureococcus anophagefferens: Causes and ecological consequences of brown tides in U.S. mid-Atlantic coastal waters; Limnol. Oceanogr. 42(5) 1023-1038.

Burkill P H, Mantoura R F C, Llewellyn C A and Owens N P J 1987 Microzooplankton grazing and selectivity of phytoplankton in coastal waters; Mar. Biol. 93 581-590.

Cloern J E 1996 Phytoplankton bloom dynamics in coastal ecosystems: A review with some general lessons from sustained investigation of San Fransisco Bay, California; Rev. Geophys. 34(2) 127-168.

Dehadrai P V and Bhargava R M S 1972 Distribution of chlorophyll, carotenoids, and phytoplankton in relation to certain environmental factors along central west coast of India; Mar. Biol. 17 30-37.
Desa E S, Suresh T, Matondkar S G P, Desa E, Goes J, Mascarenhas A, Parab S G, Shaikh N and Fernandes C E G 2005 Detection of Trichodesmium bloom patches along the eastern Arabian Sea by IRS-P4/OCM ocean colour sensor and by in-situ measurements; Indian $J$. Mar. Sci. 34(4) 374-386.

Devassy V P and Goes J I 1988 Phytoplankton community structure and succession in a tropical estuarine complex (central west coast of India); Estuarine Coast. Shelf Sci. 27 671-685.

Devassy V P and Goes J I 1989 Seasonal patterns of phytoplankton biomass and productivity in a tropical estuarine complex (west coast of India); Proc. Indian Acad. Sci. (Plant Sci.) 99 485-501.

Devassy V P, Bhattathiri P M A and Qasim S Z 1978 Trichodesmium phenomenon; Indian J. Mar. Sci. 7 168-186.

Engelkes M M 1985 Derivaatvorming en afbraak van algenpigmenten door copepodenbegrazing gemeten na scheiding met HPLC; Studentenverslag, NIOZ, Texel, The Netherlands.

Falkowski P G and LaRoche J 1991 Acclimation to spectral irradiance in algae; J. Phycol. 27 8-14.

Gibb S W, Cummings D G, Iriigoien X, Barlow R G and Mantoura R F C 2001 Phytoplankton pigment chemotaxonomy of the northeastern Atlantic; Deep-Sea Res. II $48795-823$.

Gin K Y H, Zhang S and Lee Y K 2003 Phytoplankton community structure in Singapore's coastal waters using HPLC pigment analysis and flow cytometry; J. Plank. Res. 25 1507-1519.

Godhe A, Otta S K, Rehnstam-Holm A-S, Karunasagar I and Karunasagar I 2001 Polymerase chain reaction in detection of Gymnodinium mikimotoi and Alexandrium minutum in field samples from southwest India; Mar. Biotech. 3 152-162.

Gomes H do R, Goes J I, Matondkar S G P, Parab S G, Al-Azri A R N and Prasad T 2008 Blooms of Noctiluca miliaris in the Arabian Sea - an in-situ and satellite study; Deep-Sea Res. I 55 751-765.

Guillard R R L, Keller M D, O'Kelly C J and Floyd G L 1991 Pycnococcus privasolii gen. et. sp. nov., a coccoid prasinoxanthin-containing phytoplankter from the western north Atlantic and Gulf of Mexico; J. Phycol. 27 $39-47$.

Hallaegraeff G M and Jeffrey S W 1984 Tropical phytoplankton species and pigments of continental shelf waters of north and north-west Australia; Mar. Ecol. Prog. Ser. 20 59-74.

Hasle G R 1978 Concentrating phytoplankton: The inverted microscope method; In: Phytoplankton manual, monographs on oceanographic methodology (ed.) Sournia A, Paris: UNESCO, 6 88-96.

Janse I, van Rijssel M, Ottema A and Gottschal J C 2001 Microbial breakdown of Phaeocystis mucopolysaccharides; Limnol. Oceanogr. 44(6) 1447-1457.

Jeffrey S W, Wright S W and Zapata M 1999 Recent advances in HPLC pigment analysis of phytoplankton; Mar. Freshwat. Res. 50 879-896.

Karunasagar I and Karunasagar I 1992 Gymnodinium nagasakiense red tide off Someshwar, west coast of India and mussel toxicity; J. Shellfish Res. 11 477-478.

Karunasagar I, Karunasagar I, Oshima Y and Yasumoto T 1990 Toxin profile of shellfish involved in outbreak of paralytic shellfish poisoning in India; Toxicon $\mathbf{2 8}$ 868-870.

Karunasagar I, Segar K and Karunasagar I 1989 Incidence of paralytic shellfish poison (PSP) and diarrhoetic shellfish poison (DSP) in shell-fishes in Karnataka; In: Red tides: Biology, Environmental Science and Toxicology 
(eds) Okaichi T, Anderson D M, Nemoto T (New York: Elsevier Science), pp. 59-62.

Latasa M, Scharek R, Le Gall F and Guillou L 2004 Pigment suites and taxonomic groups in Prasinophyceae; J. Phycol. 40 1149-1155.

Lorenzen C J and Jeffrey S W 1980 Determination of chlorophyll in seawater; UNESCO Tech. Paper Mar. Sci., UNESCO.

Mackey M D, Mackey D J, Higgins H W and Wright S W 1996 CHEMTAX-a program for estimating class abundances from chemical markers: Application to HPLC measurements of phytoplankton; Mar. Ecol. Prog. Ser. $144265-283$.

Mackey D J, Higgins H W, Mackey M D and Holdsworth D 1998 Algal class abundances in the western equatorial Pacific: Estimation from HPLC measurements of chloroplast pigments using CHEMTAX; Deep-Sea Res. I 45(9) 1441-1468.

Madhupratap M and Haridas P 1990 Zooplankton, especially calanoid copepods in the upper $1000 \mathrm{~m}$ of the southern Arabian Sea; J. Plank. Res. 12 305-321.

Madhupratap M, Sawant S S and Gauns M 2000 A first report on a bloom of the marine prymnesiophycean, Phaeocystis globosa from the Arabian Sea; Oceanol. Acta 23(1) 83-90.

McManus G B and Dawson R 1994 Phytoplankton pigments in the deep chlorophyll maximum of the Caribbean Sea and the western tropical Atlantic Ocean; Mar. Ecol. Prog. Ser. 113 199-206.

Naqvi S W A, George M D, Narvekar P V, Jayakumar D A, Shailaja M S, Sardessai S, Sarma V V S, Shenoy D M, Naik H, Maheswaran P A, Krishnakumari K, Rajesh G, Sudhir A K and Binu M S 1998 Severe fish mortality associated with 'red tide' observed in the sea off Cochin; Curr. Sci. 75(6) 543-544.

Naqvi S W A, Naik H and Narvekar P V 2003 The Arabian Sea; In: Biogeochemistry of marine systems (eds) Black K, Shimmield G B (Oxford: Blackwell), pp. 157-207.

Nayar S, Gupta T R C and Prabhu H V 2001 Bloom of Noctiluca scintillans MaCartney in the Arabian Sea off Mangalore Southwest India; Asian Fish Sci. 14 77-82.

Nayak B B, Karunasagar I and Karunasagar I 2000 Bacteriological and physico-chemical factors associated with Noctiluca miliaris bloom along Mangalore south west coast of India; Indian J. Mar. Sci. 29 139-143.

Neetu S, Shetye S R and Chandramohan P 2006 Impact of sea breeze on the wind-seas off Goa, west coast of India; J. Earth Syst. Sci. 115(2) 229-234.

Parab S G, Matondkar S G P, Gomes H do-R and Goes J I 2006 Monsoon driven changes in phytoplankton populations in the eastern Arabian Sea as revealed by microscopy and HPLC pigments; Continent. Shelf Res. $262538-2558$.

Qasim S Z 1977 Biological productivity of the Indian Ocean; Indian J. Mar. Sci. 6 122-137.

Ramaiah N, Paul J T, Fernandes V, Raveendran T, Raveendran O, Sundar D, Revichandran C, Shenoy D M, Manguesh G, Kurien S, Gerson V J, Shoji D T, Madhu N V, Sreekumar S, Lokabharathi P A and Shetye S R 2005 The September 2004 stench off the southern Malabar coast - A consequence of holococcolithophore bloom; Curr. Sci. 88(4) 551-554.

Reigman R and Kraay G W 2001 Phytoplankton community structure derived from HPLC analysis of pigments in the Faroe-Shetland channel during summer 1999: The distribution of taxonomic groups in relation to physical/ chemical conditions in the photic zone; J. Plank. Res. 23 191-205.

Roy R 2010 Short-term variability in halocarbons in relation to phytoplankton pigments in coastal waters of the central eastern Arabian Sea; Estuarine Coast. Shelf Sci. 88 311-321.

Roy R, Pratihary A, Gauns M and Naqvi S W A 2006 Spatial variation of phytoplankton pigments along the southwest coast of India; Estuarine Coast. Shelf Sci. 69 189-195.

Sahayak S, Jyothibabu R, Jayalakshmi K J, Habeebrehman H, Sabu P, Prabhakaran M P, Jasmine P, Shaiju P, Rejomon G, Thresiamma J and Nair K K C 2005 Red tide of Noctiluca miliaris off south of Thiruvananthapuram subsequent to the 'stench event' at the southern Kerala coast; Curr. Sci. 89(9) 1472-1473.

Sarangi R, Chauhan P and Nayak S R 2004 Detection and monitoring of Trichodesmium blooms in the coastal waters off Saurashtra, India using IRS-P4 OCM data; Curr. Sci. 86(12) 1636-1641.

Sawant S and Madhupratap M 1996 Seasonality and composition of phytoplankton in the Arabian Sea; Curr. Sci. 71(11) 869-873.

Schluter L and Møhlenberg F 2003 Detecting presence of phytoplankton groups with non-specific pigment signatures; J. Appl. Phycol. 15 465-476.

Shetye S 1999 Dynamics of circulation of the waters around India; In: Present trends and future directions in Ocean Science, Indian National Science Academy, New Delhi, pp. $1-21$.

Shetye S, Gouveia A D and Shenoi S S C 1994 Circulation and water masses of the Arabian Sea; Proc. Indian Acad. Sci. (Earth Planet. Sci.) 103(2) 107-123.

Strom S L 1993 Production of phaeopigments by marine protozoa: Results of laboratory experiments analysed by HPLC; Deep-Sea Res. I 40 57-80.

Subba Rao D V 2005 Comprehensive review of the records of the biota of the Indian Seas and introduction of non-indigenous species; Aquat. Conser. Mar. Freshwater Ecosyst. 15 117-126.

Subrahmanyan R 1958 Studies on the phytoplankton of the west coast of India, Part-I; pp. 113-187.

Trees C C, Kennicutt M C and Brooks J M 1985 Errors associated with standard fluorometric determination of chlorophylls and phaeopigments; Mar. Chem. 17 $1-12$.

Trees C C, Clark D K, Bidigare R R, Ondrusek M E and Mueller J L 2000 Accessory pigments versus chlorophyll $a$ concentrations within the euphotic zone: An ubiquitous relationship; Limnol. Oceanogr. 45 1130-1143.

UNESCO 1994 Determination of bacterial production using methyl-tritiated thymidine; In: Protocols for the Joint Global Ocean Flux Study (JGOFS), Manual and Guides 29 163-169.

van Heukelem 2002 HPLC phytoplankton pigments: Sampling, laboratory methods and quality assurance procedure; In: Ocean optics protocols for Satellite Ocean Color Sensor (eds) Mueller J, Fragion G, Revision 3, Volume 2, NASA technical memorandum 2002-210004, pp. 258-268. Yu Z-G, Deng C-M, Peng Y, Yu Z and Qian S-B 2007 Prasinoxanthin containing Prasinophyceae discovered in Jia Zhou Bay, China; J. Integ. Plant. Biol. 49 497-506. 